\title{
ERRATA
}

\section{Rectus Abdominis Free-Tissue Transfer in Lower Extremity Reconstruction: Review of 40 Cases}

\section{Ramzi Musharrafieh, ${ }^{1}$ George Macari, ${ }^{1}$ Shadi Hayek, ${ }^{1}$ Bassem Elhassan, ${ }^{1}$ and Bishara Atiyeh ${ }^{1}$}

The publisher regrets a typographical error in the name spelled "Bassem El Hassan" in the above article in Journal of Reconstructive Microsurgery, Volume 16, Number 5, 2000, p. 341. The corrected spelling appears above.

${ }^{1}$ Department of Orthopaedic Surgery, American University of Beirut Medical Center, Beirut, Lebanon.

Address for correspondence and reprint requests: Dr. Ramzi Musharrafieh, c/o American University of Beirut, New York Office, 850 Third Avenue, 18 Floor, New York, NY 10022.
J Reconstr Microsurg 2007;23:120. Copyright (C) 2007 by Thieme Medical Publishers, Inc., 333 Seventh Avenue, New York, NY 10001, USA. Tel: +1(212) 584-4662.

DOI 10.1055/s-2007-971081. ISSN 0743-684X. 